\title{
Management of focal intracranial infections: is medical treatment better than surgery?
}

\author{
D Leys, J L Christiaens, Ph Derambure, J P Hladky, F Lesoin, M Rousseaux, M Jomin, \\ H Petit
}

\begin{abstract}
Three groups of patients with single hemispheric brain abscesses or subdural empyemas, from 1 to $5 \mathrm{~cm}$ large, with similar initial prognosis, have been treated either by medical treatment alone (20), aspiration (21), or excision (15). Differences in survival were not found, but medical treatment alone was better for long term sequelae. Surgical procedures (either aspiration or excision) were better for both isolation of the organism and the hospital stay before discharge. In spite of good results, it is unwise to conclude too strongly in favour of no surgical treatment as this study was not randomised.
\end{abstract}

During the past decade the use of CT for diagnosis and follow up of focal intracranial infections has modified the management of brain abscesses ${ }^{1-3}$ and subdural intracranial empyemas. ${ }^{4-6}$ Because the follow up of these patients is now easier, medical treatment alone, or aspiration without excision are possible in most cases. ${ }^{36-7}$ From the medical literature it appears that: 1) most authors agree with the need for surgery, ${ }^{8-9}$ 2) antibiotics are always necessary, ${ }^{3}$ 3) total recovery using medical treatment alone is possible in selected patients with brain asbscesses ${ }^{1-3}$ or subdural intracranial empyemas ${ }^{4-6}$ especially in cases with a small size lesion,,$^{2-3}$ with multiple locations ${ }^{1011}$ or located in surgically inaccessible areas, ${ }^{7}$ and in patients without severe deterioration of consciousness, 4) medical treatment alone usually provides good functional result ${ }^{12} 5$ ) a few cases of large focal intracranial infections recovered totally after medical treatment alone. ${ }^{3713}$ Nevertheless, we do not know if medical treatment alone is better than surgery, and if so, if this reflects its use in patients with a lower initial severity.

Many agree with the value of medical treatment, ${ }^{14}$ but there is no agreement about whether or not surgery (aspiration or excision), should also be performed routinely. ${ }^{15}$ In view of this disagreement we were able to select, over a period of four years, a population of consecutively treated patients with similar initial prognosis and we have compared the results of the three procedures.

\section{Patients and method}

We studied 79 patients treated consecutively for a focal intracranial infection between 1
January 1984 and 31 December 1987. All were over the age of 18 years. The diagnosis was made in each case by CT criteria. ${ }^{1315}$ It was confirmed preoperatively in the surgical groups. In other patients confirmation was obtained from the disappearance of the CT abnormalities after antibiotic treatment and by necropsy.

\section{Treatment}

In the "medical treatment alone" group, we included patients who were not treated by aspiration or excision. We considered as treated by "medical treatment alone" one patient, with AIDS and multiple brain abscesses, who died during the third day of medical treatment in spite of an aspiration performed a few minutes earlier, when his condition suddenly deteriorated. No other patient was treated surgically after more than a 24 hours course of medical treatment. Medical treatments, both for brain abscesses $^{3}$ and subdural intracranial empyemas were previously reported in detail. ${ }^{6}$ Patients were usually treated daily with ceftriaxone $(2$ or $3 \mathrm{~g}$ iv), pefloxacine ( $800 \mathrm{mg} \mathrm{im}$ ) and metronidazole $(1.5 \mathrm{~g} \mathrm{iv})$ except when these antibiotics failed to be effective in vitro against the causative organisms. In such cases we used thiophenicol ( 3 to $4.5 \mathrm{~g}$ iv) or ampicillin ( 8 to 12 $\mathrm{g}$ iv), or trimethoprim-sulfamethoxazole ( 320 $\mathrm{mg}-1600 \mathrm{mg})$. Brain oedema was initially treated with mannitol $(10 \%)$ and after 24 hours by tetracosactide $(0.5$ to $1 \mathrm{mg}$ iv or im).

In the group termed "aspiration", we included patients who received up to 24 hours of medical treatment following the diagnosis of a focal intracranial infection who had aspiration via a Cushing needle via a burr hole. The focal intracranial infection was never evacuated completely, to avoid secondary haemorrhage, and antibiotics (framycetin or gentamycin) were introduced into the cavity. Aspiration was sometimes repeated several times. Stereotactic aspiration was not performed in this study.

In the "excision" group we included patients in whom total excision of the focal intracranial infections was performed via a craniotomy, either immediately after diagnosis or after one of the two procedures described.

\section{Choice of treatment}

It was not possible, for ethical reasons, to randomise the choice of treatment. This choice was performed by the neurologist or by the neurosurgeon in charge of the patient, on the perceived best procedure. Surgical treatment of the source of infection was performed each 
Table 1 Information collected

Sex: male/female

Age (years)

Age (years)

mber of brain abscesses or subdural intracranial empyemas: single/multiple

Location of brain abscesses or subdural intracranial empyemas: hemispheres/posterior fossa/multiple/subdural intracrania empyemas

Primary source of infection

Causative organism

Level of consciousness is rated using the Glasgow's coma scale ${ }^{17}$

Generalised seizures: $0=$ no seizure $/ 1=$ one seizure $/ 2=$ more than 1 seizure $/ 3=$ status epilepticus

Focal seizures: $0=$ no seizure $/ 1=$ one seizure $/ 2=$ more than 1 seizure $/ 3=$ status epilepticus

Hemiplegia: $0=$ no deficit $/ 1=$ mild deficit $/ 2=$ severe deficit

Hemian- (hypo-) esthesia: $0=$ no deficit $/ 1=$ mild deficit $2=$ severe deficit

Aphasia: $0=$ no deficit $/ 1=$ mild deficit $/ 2=$ severe deficit

Minor hemisphere neuropsychological disturbances: $0=$ no deficit $1=$ mild deficit $/ 2=$ severe deficit

Hemianopsia: $0=$ no deficit $/ 1=$ mild deficit $/ 2=$ severe deficit

Other deficits: $0=$ no deficit $/ 1=$ mild deficit $/ 2=$ severe defici

Previous state of health: Good health/Other illness with low vital risk within 1 year/Other illness with high vital risk within 1 year

Treatment of brain abscesses or subdural intracranial empyemas: medical alone/Aspiration/Excision

Surgical treatment of the primary source of infection: Yes/No

Duration between the first sign and treatment (days)

Duration of antibiotics (days)

Duration of antioedematous treatment (days)

Death after 1 month: Yes/No

Death after 1 month: Yes/No
Death after 3 months: Yes/No

Death after 3 months: Yes/No
Death after 1 year: $\mathrm{Yes} / \mathrm{No}$

Death after 1 year: Yes/No

Relation between death and brain abscesses (or subdural intracran ial empyemas) or their treatment: Yes/No

Seizures after 1 year: $0=$ no seizure without treatment $/ 1=$ no seizure under treatment $/ 2=$ infrequent seizures under treatment $/ 3=$ frequent seizures under treatment

Focal deficits after 1 year: $0=$ no deficit $/ 1=$ mild deficit $2=$ severe deficit

Duration before discharge including rehabilitation (days)

Social prognosis: Works again/Doesn't work

The total number of $C T$ scans to which the patients were subjected after three and 12 months including the first CT scan from which the diagnosis was made. Patients dead or lost to follow up before these dates were not studied for this item.

time it was thought necessary, even in those patients whose intracranial infection was treated medically. The neurologists and the neurosurgeons involved in this study had more than five years experience. They did not modify their usual practice for this study.

Storage and analysis of data

Data were stored and analysed with a microcomputer. We collected epidemiological data, prognosis factors, therapeutic modalities and results during the first year (table 1 ).

\section{Comparison of initial factors of prognosis}

We first studied if prognostic factors were balanced in the three groups. Statistical assessment used the Chi-square test (sometimes with Yates correction) to study sex, primary source of infection, generalised seizures, focal seizures, hemiplegia, hemian-(hypo-) aesthesia, aphasia, minor hemisphere neuropsychological disturbances, and hemianopia. Other deficits were also tested as was the previous state of health, surgical treatment of the primary source of infection, and ANOVA one way analysis of variants for age, duration between the first clinical sign and the onset of treatment, size of the focal intracranial infection, level of consciousness, duration of antibiotics, and of antioedematous treatment.

\section{Choice of the population studied}

When one or more prognostic factors were not balanced between the three groups of patients, we withdrew from the initial sample of 79 patients, any patient with the less frequent value, aiming to keep only patients belonging to the same class for this item. The following part of the study was performed only from the cases selected by this procedure.

\section{Statistical comparison of the results of the three methods of treatment}

We compared the three groups (medical treatment alone/aspiration/excision), in the numbers of deaths (after one month, three months, and one year), the relation between death and the focal intracranial infection or its treatment, and the social outcome, using the Chi-square test (sometimes with Yates correction). The comparison of sequelae after one year (seizures or focal deficits), and the number of CT scans performed after three and 12 months was performed using Kruskal-Wallis non parametric $\mathrm{H}$ test. The comparison of the duration of hospital stay was performed using analysis of variancy (ANOVA 1 way).

\section{Results}

Comparison of initial prognostic factors

Study of the distribution of the prognostic factors between the three groups showed that there were significant differences 1 ) in the number of focal intracranial infections (more multiple locations in non surgically treated patients, $p<0.05$ ), 2) in the location of the focal intracranial infections (more hemispheric abscesses in non surgically treated patients, $p$ $<0.05$ ), and 3 ) in the size of the focal intracranial infections (more focal intracranial infections smaller than $1 \mathrm{~cm}$ in non surgically treated patients, $p<0.05$, and larger than $5 \mathrm{~cm}$ in surgically treated patients $p<0.05$ ).

\section{Choice of the study population}

For the study, we withdrew multiple focal intracranial infections ( 21 cases), focal intracranial infections located in the posterior fossa (six cases), and focal intracranial infections smaller than $1 \mathrm{~cm}$ or larger than $5 \mathrm{~cm}$ (four cases). Some patients had two or three such criteria. We retained 56 cases with a single hemisphere focal intracranial infection of 1 to 5 $\mathrm{cm}$. We then confirmed that in this new population, there was no difference in the distribution of the factors for prognosis between the three groups, whose characteristics are summarised in table 2 .

\section{Statistical analysis of the results of the three procedures}

Data are reported in table 3. The analysis failed to reveal any statistical difference between the numbers of deaths (after one month, three months, and one year), among the three groups; neither did it in the relation between death and focal intracranial infections or its treatment, nor in social outcome $(0.05<\mathrm{p}<$ $0 \cdot 1)$. Sequelae were more severe in surgically treated patients; this applied to seizures ( $p<$ 0.02 ) and focal deficits $(p<0.05)$. The causative organism was significantly more often isolated in surgical cases, whether this was by aspiration or excision $(p<0.01)$. The 
Table 2 Comparison of initial prognostic factors in three groups

\begin{tabular}{|c|c|c|c|c|c|}
\hline & & $\begin{array}{l}\text { Medical } \\
\text { treatment } \\
\text { alone } \\
n=20\end{array}$ & $\begin{array}{l}\text { Aspiration } \\
n=21\end{array}$ & $\begin{array}{l}\text { Excision } \\
n=15\end{array}$ & $p^{\star \star}$ \\
\hline Sex & $\begin{array}{l}\text { Male } \\
\text { Female }\end{array}$ & $\begin{array}{r}11 \\
9\end{array}$ & $\begin{array}{r}15 \\
6\end{array}$ & $\begin{array}{r}12 \\
3\end{array}$ & NS \\
\hline Age (years) $)^{\star}$ & & $\begin{array}{l}38 \cdot 05 \\
(2 \cdot 80)\end{array}$ & $\begin{array}{l}39 \cdot 29 \\
(4 \cdot 15)\end{array}$ & $\begin{array}{l}40 \cdot 00 \\
(4 \cdot 02)\end{array}$ & NS \\
\hline Point of entry & $\begin{array}{l}\text { Local } \dagger \\
\text { General }+\dagger\end{array}$ & $\begin{array}{l}9 \\
7\end{array}$ & $\begin{array}{r}14 \\
7\end{array}$ & 11 & NS \\
\hline Size of the lesion (mm) & & $\begin{array}{l}29 \cdot 8 \\
(2 \cdot 44)\end{array}$ & $\begin{array}{l}29 \cdot 43 \\
(2 \cdot 31)\end{array}$ & $\begin{array}{l}30 \cdot 73 \\
(2 \cdot 69)\end{array}$ & NS \\
\hline Location & $\begin{array}{l}\text { Frontal } \\
\text { Parieto-occipital } \\
\text { Temporal } \\
\text { Subdural empyema }\end{array}$ & $\begin{array}{l}4 \\
5 \\
6 \\
5\end{array}$ & $\begin{array}{l}8 \\
4 \\
6 \\
3\end{array}$ & $\begin{array}{l}5 \\
5 \\
3 \\
2\end{array}$ & NS \\
\hline Glasgow's scores of cons & $\begin{array}{l}\text { ousness } \\
\text { Range } \\
\text { Median }\end{array}$ & $11^{7-13}$ & ${ }_{10}^{6-13}$ & ${ }^{6-14}$ & NS \\
\hline Generalised seizures & $\begin{array}{l}\text { No } \\
\text { Yes }\end{array}$ & $\begin{array}{r}17 \\
3\end{array}$ & $\begin{array}{r}14 \\
7\end{array}$ & $\begin{array}{l}9 \\
6\end{array}$ & NS \\
\hline Focal seizures & $\begin{array}{l}\text { No } \\
\text { Yes }\end{array}$ & $\begin{array}{r}15 \\
5\end{array}$ & $\begin{array}{r}16 \\
5\end{array}$ & $\begin{array}{r}10 \\
5\end{array}$ & NS \\
\hline Hemiplegia & $\begin{array}{l}\text { Absent or mild } \\
\text { Severe }\end{array}$ & $\begin{array}{r}16 \\
4\end{array}$ & $\begin{array}{r}14 \\
7\end{array}$ & $\begin{array}{r}13 \\
2\end{array}$ & NS \\
\hline Hemianaesthesia & $\begin{array}{l}\text { Absent or mild } \\
\text { Severe }\end{array}$ & $\begin{array}{r}20 \\
0\end{array}$ & $\begin{array}{r}18 \\
3\end{array}$ & $\begin{array}{r}11 \\
4\end{array}$ & NS \\
\hline Aphasia & $\begin{array}{l}\text { Absent or mild } \\
\text { Severe }\end{array}$ & $\begin{array}{r}19 \\
1\end{array}$ & 20 & $\begin{array}{r}14 \\
1\end{array}$ & NS \\
\hline Hemianopsia & $\begin{array}{l}\text { Absent or mild } \\
\text { Severe }\end{array}$ & $\begin{array}{r}19 \\
1\end{array}$ & $\begin{array}{r}17 \\
4\end{array}$ & $\begin{array}{r}11 \\
4\end{array}$ & NS \\
\hline MHND§ & $\begin{array}{l}\text { Absent or mild } \\
\text { Severe }\end{array}$ & $\begin{array}{r}20 \\
0\end{array}$ & $\begin{array}{r}19 \\
2\end{array}$ & $\begin{array}{r}14 \\
1\end{array}$ & NS \\
\hline Other deficits & $\begin{array}{l}\text { Absent or mild } \\
\text { Severe }\end{array}$ & $\begin{array}{r}17 \\
3\end{array}$ & $\begin{array}{r}17 \\
4\end{array}$ & $\begin{array}{r}15 \\
0\end{array}$ & NS \\
\hline \multicolumn{2}{|c|}{ Time from first symptom to treatment (days) ${ }^{\star \star}$} & $\begin{array}{c}8 \cdot 3 \\
(1 \cdot 35)\end{array}$ & $\begin{array}{c}7.95 \\
(1 \cdot 10)\end{array}$ & $\begin{array}{l}8 \\
(1 \cdot 16)\end{array}$ & NS \\
\hline Previous state of health & $\begin{array}{l}\text { Normal } \\
\text { Without vital risk|| } \\
\text { With vital risk } \|\end{array}$ & $\begin{array}{r}15 \\
3 \\
2\end{array}$ & $\begin{array}{r}19 \\
1 \\
1\end{array}$ & $\begin{array}{r}10 \\
3 \\
2\end{array}$ & NS \\
\hline \multicolumn{6}{|c|}{ Surgery for primary source of infection } \\
\hline \multicolumn{2}{|c|}{ Duration of antibiotics (days) } & $\begin{array}{c}12 \\
8 \\
113.45 \\
(10 \cdot 02)\end{array}$ & $\begin{array}{l}11 \\
10 \\
89 \cdot 15 \\
(10 \cdot 49)\end{array}$ & $\begin{array}{c}9 \\
6 \\
107 \cdot 92 \\
(27 \cdot 74)\end{array}$ & $\begin{array}{l}\text { NS } \\
\text { NS }\end{array}$ \\
\hline \multicolumn{2}{|c|}{ Duration of antioedematous (days) ${ }^{\star}$} & $\begin{array}{l}11 \cdot 77 \\
(3 \cdot 43)\end{array}$ & $\begin{array}{r}8.47 \\
(3.46)\end{array}$ & $\begin{array}{r}6 \cdot 78 \\
(2 \cdot 25)\end{array}$ & NS \\
\hline
\end{tabular}

$\star$ Mean and standard error.

† Sinusitis ( 6 cases), otitis ( 11 cases), dental infection ( 3 cases), trauma ( 3 cases), post-operative (11 cases).

†+Endocarditis ( 1 case), pulmonary angioma ( 3 cases), vena cava abnormality ( 1 case), pulmonary infection (8 cases), septicemia (4 cases).

\$Minor hemisphere disturbances.

Osler-Weber's disease ( 3 cases), alcoholism ( 3 cases), diabetes mellitus ( 1 case).

AIDS ( 2 cases), hemodialysis for severe chronic renal failure ( 1 case), glioblastoma ( 1 case), leukaemia (1 case).

$\star \star$ Significant if $\mathrm{p}<0.05$.

Table 3 Comparison of the results

\begin{tabular}{|c|c|c|c|c|c|}
\hline & & $\begin{array}{l}\text { Medical } \\
\text { treatment } \\
\text { alone } \\
n=20\end{array}$ & $\begin{array}{l}\text { Puncture } \\
n=21\end{array}$ & $\begin{array}{l}\text { Excision } \\
n=15\end{array}$ & pq \\
\hline Death (1 month) & Yes & 0 & 2 & 0 & NS \\
\hline Death (3 months) & No & 20 & $\begin{array}{r}3 \\
16\end{array}$ & $\begin{array}{r}0 \\
15\end{array}$ & \\
\hline \multirow{2}{*}{ Death (1 year) } & Yes & 1 & 3 & 1 & NS \\
\hline & \multicolumn{4}{|c|}{ Relation between death and abscess or treatment } & \\
\hline 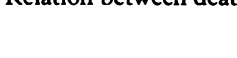 & $\begin{array}{l}\text { Yes } \\
\text { No }\end{array}$ & $\begin{array}{ll}0 \\
1+\dagger\end{array}$ & $\begin{array}{l}1^{\star} \\
2 \S\end{array}$ & $\begin{array}{l}1 \dagger \\
0\end{array}$ & NS \\
\hline Sequelae & $\begin{array}{l}\text { No; without treat- } \\
\text { ment }\end{array}$ & 16 & 6 & 3 & \\
\hline Seizures & $\begin{array}{l}\text { No; under treatment } \\
\text { Infrequent seizures } \\
\text { Frequent seizures } \\
\text { Lost to follow up }\end{array}$ & $\begin{array}{l}1 \\
0 \\
1 \\
1\end{array}$ & $\begin{array}{l}0 \\
6 \\
2 \\
4\end{array}$ & $\begin{array}{l}6 \\
3 \\
0 \\
2\end{array}$ & $\mathrm{p}<0.02$ \\
\hline $\begin{array}{l}\text { Sequelae: } \\
\text { Focal deficits }\end{array}$ & $\begin{array}{l}\text { No focal deficit } \\
\text { Mild focal deficit } \\
\text { Severe focal deficit } \\
\text { Dropped out }\end{array}$ & $\begin{array}{r}17 \\
1 \\
0 \\
1\end{array}$ & $\begin{array}{l}7 \\
6 \\
1 \\
4\end{array}$ & $\begin{array}{l}5 \\
3 \\
4 \\
2\end{array}$ & $\mathrm{p}<0.001$ \\
\hline \multicolumn{2}{|c|}{ 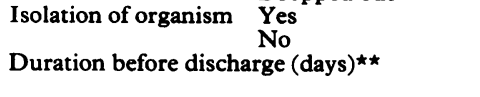 } & $\begin{array}{l}4 \\
16 \\
73 \cdot 11 \\
(8 \cdot 88)\end{array}$ & $\begin{array}{c}13 \\
8 \\
43 \cdot 29 \\
(5 \cdot 47)\end{array}$ & $\begin{array}{l}10 \\
5 \\
47 \\
(7 \cdot 11)\end{array}$ & $\begin{array}{l}\mathrm{p}<0.01 \\
\mathrm{p}<0.02\end{array}$ \\
\hline $\begin{array}{l}\text { Social prognosis } \\
\text { Number of CT scans }\end{array}$ & $\begin{array}{l}\text { Works again } \\
\text { Does not work } \\
3 \text { months) })^{\star \star}\end{array}$ & $\begin{array}{l}17 \\
2 \\
9 \cdot 00 \\
(0 \cdot 36)\end{array}$ & $\begin{array}{c}11 \\
7 \\
7.67 \\
(0.61)\end{array}$ & $\begin{array}{l}7 \\
6 \\
6.8 \\
(0.64)\end{array}$ & $\begin{array}{l}\text { NS }(p<0.10) \\
p<0.02\end{array}$ \\
\hline Number of CT Scans & 12 months $)^{\star \star}$ & $\begin{array}{l}10 \cdot 75 \\
(0 \cdot 32)\end{array}$ & $\begin{array}{r}8.22 \\
(0.58)\end{array}$ & $\begin{array}{r}6.93 \\
(0.69)\end{array}$ & $\mathrm{p}<0.001$ \\
\hline
\end{tabular}

^Haemorrhage after aspiration.

† Status e
+ +AIDS.

$\S$ Glioblastoma and leukaemia. duration of hospital stay was shorter in surgically treated patients $(p<0.02)$. The non surgically treated patients had a significantly higher number of CT scans within the first three and 12 months (respectively $p<0.02$ and $\mathrm{p}<0.001$ ). The analysis failed to reveal any difference between the two surgical procedures (aspiration or excision) in terms of sequelae (seizures or focal deficits) or isolation of causative organisms.

During the four years of this study, we erroneously diagnosed as brain abscesses three cases of tumours, the diagnosis was made in each case, after eight to 18 days of antibiotics. Excision was performed in eight cases because of an erroneous clinical and radiological diagnosis of tumour.

\section{Discussion}

In three groups of patients that were selected to have a similar initial prognosis (single hemispheric focal intracranial infections from 1 to 5 $\mathrm{cm}$ ), our study failed to reveal any difference between the three methods of management in terms of survival, mechanism of death and social outcome. Sequelae (seizures or focal deficits) were more frequent and more severe after surgery (either aspiration or excision).

Though this study is, to our knowledge, the first in which such a comparison between these three procedures was possible in patients with the same initial prognosis, it would be wise not to conclude too strongly in favour of non surgical treatment. The study was not a prospective one neither was the choice of the procedure randomised. The lack of previous comparative studies on patients with a similar initial prognosis, leads to ethical difficulties in proposing randomisation between surgery and medical treatment alone. Our results might enable future prospective studies without such ethical problems.

There was no fundamental difference in the choice of the treatment for multiple focal intracranial infections or for focal intracranial infections smaller than $1 \mathrm{~cm}$; operations were not carried out on these; focal intracranial infections larger than $5 \mathrm{~cm}$ or located in the posterior fossa, were treated surgically, except in one case. The choice of the treatment differed only for single hemispheric focal intracranial infections sized between 1 and 5 $\mathrm{cm}$. That a clearly superior form of management did not emerge, indicates that in individual cases the clinical acumen of the neurologist or neurosurgeon was well founded.

No significant differences were found in the distribution of initial prognostic factors; differences too small to be detected by statistical analysis might exist and might be a cause of bias in the analysis. Moreover, the number of patients was small and some differences appeared with respect to the location of the abscesses and the most common form of treatment. Thus surgery was used more commonly in frontal lesions. A larger population, obtained by a multicentre study might ensure a better balance of prognostic factors.

In the selected population, our study suggested that medical treatment alone provided 
better functional results without a higher mortality, even though isolation of the causative organism was achieved less often. This result agrees with previously reported findings. ${ }^{2-8} 10121415$ However, we think that surgery is always necessary when a focal intracranial infection enlarges on CT, despite medical treatment, ${ }^{36815}$ to identify the type of the organism and its sensitivity to antibiotics. This was not necessary in the past four years in our experience, except for three tumours erroneously diagnosed as brain abscesses. The increasing prevalence of AIDS and the possibility of toxoplasma might make it more necessary. The duration of antibiotic treatment was not significantly higher in non surgically treated patients, but the hospital stay was longer. We think that it is not a serious disadvantage if further studies confirm that functional results are better and survival identical using a non surgical method. Moreover, from an economic point of view, the long term care would probably be cheaper because of fewer sequelae. ${ }^{2}$

Our study failed to reveal any difference between the results of aspiration or excision in surgically treated patients. This does not mean that these treatments are equivalent. There is a trend for more sequelae after excision but it was not possible to prove this with such a small population. Moreover, neuropsychological assessment may have been insufficient to detect subtle changes.

Despite the cautionary points, our study suggests the superiority of medical treatment over the surgical methods used, especially concerning sequelae. These results cannot be generalised to brain abscesses or subdural intracranial empyemas other than single hemispheric lesions from 1 to $5 \mathrm{~cm}$. A prospective multicentre study, using the methodology of the EC/IC bypass study group ${ }^{16}$ would be useful to validate our findings and discover to which other cases they can be extended.

1 Claveria LE, Du Boulay GH, Moseley IF. Intracranial infections: investigations by computed axial tomography. Neuroradiology 1976;12:59-71.

2 Rosenblum ML, Hoff JT, Norman D, Weinstein PR, Pitts L. Decreased mortality from brain abscesses since advent of computerised tomography. $J$ Neurosurg 1978 49:658-68.

3 Petit H, Rousseaux M, Lesoin F, Destee A, Clarisse J, Warot P. Primauté du traitement médical des abcès cérébraux (19 cas). Rev Neurol (Paris) 1983;139:575-81.

4 Rosazza A. De Triboulet N, Deonna TH. Non surgical treatment of interhemispheric subdural empyemas. Helv Paed Acta 1979;34:577-81.

5 Rousseaux M, Lesoin F, Jomin M. Traitement médical d'un empyème sous-dural parasagittal. Presse Méd 1984;13:2153.

6 Leys D, Desté A, Petit H, Warot P. Management of subdural intracranial empyemas should not always require surgery. J Neurol Neurosurg Psychiatry 1986;49:635-9.

7 Petit H, Destée A, Leys D, Warot P. Volumineux abcès listérien du tronc cérébral. Effet favorable de l'antibiothérapie. Rev Neurol (Paris) 1983;139:149-54.

8 Kamin $M$, Biddle $D$. Conservative management of focal intracerebral infection. Neurology (Minneap) 1981;31: intrace.

9 Williams B. Subdural empyema. In: Krayenbuhl H, ed. Advances and Technical Standards in Neurosurgery, Vol 9. New York: Springer-Verlag, 1983:133-70.

10 George B, Roux F, Pillon M, Thurel C, George C Relevance of antibiotics in the treatment of brain abscesses. Report of a case with eight simultaneous brain abscesses treated and cured medically. Acta neurochir (Wien) 1979;47:285-91.

1 Kottas M, Smith LG. A possible new approach to the management of brain abscesses. Infection 1978;6:81-3.

12 Rousseaux M, Lesoin F, Destée A, Jomin M, Petit H. Long term sequelae of hemispheric abscesses as a function of the treatment. Acta neurochir (Wien) 1985;74:61-7.

13 Whelan MA, Hilal SK. Computed tomography as a guide in the diagnosis and follow up of brain abscesses. Radiology, 1980;135:663-71.

14 Heineman HS, Braude AI, Osterholm JL. Intracranial suppurative disease. Early presumptive diagnosis and successful treatment without surgery. JAMA 1971 218:1542-7.

15 Firsching R, Karimi-Nejad A. Hirnabszeß: Operative oder konservative Behandlung? Nervenarzt 1986;57:599-603.

16 The EC/IC Bypass Study Group. Failure of extracranialintracranial arterial bypass to reduce the risk of ischemic stroke. Results of an International Randomised Trial. New Engl J Med 1985;313:1191-200.

17 Plum F, Posner JB. The diagnosis of stupor and coma Contemporary Neurology series, 17. Davis Philadelphia. 1980. 